\title{
ejavecJOURNAL EAST JAVA ECONOMIC JOURNAL

\section{POTENTIAL OF MICRO, SMALL AND MEDIUM BUSINESS (MSME) PROCESSING INDUSTRY SECTOR EAST JAVA IN RESPONDING TO THE CHALLENGES OF GLOBALIZATION}

\author{
Angginta Ramdani Ibrahim ${ }^{*}$ \\ ${ }^{1}$ Undergraduate Student of Industrial Engineering, Universitas Indonesia, Indonesia
}

\begin{abstract}
The global competition demands Indonesia to compete with other countries in the international market. East Java is a province that gives a big contribution to Indonesia's GDP. From year to year, the source of economic growth in East Java is still dominated by the processing industry, especially by the Small and Medium-Sized Enterprises (SMEs) sector. This sector is able to contribute more than 50\% to East Java's gross domestic product (GDP). Considering that, the sectoral development could be more effective to deploy in this sector for it is the prime mover of East Java's economy. In addition to the contribution to GDP, this sector is also able to solve the employment issues and the demand fulfillment. To collect the data, the writer used a questionnaire to gain the primary data with the East Java SMEs players as the respondents. Then the data was processed using the Balanced Scorecard approach to measure SMEs' performance. Besides that, the writer also used the secondary data obtained by the literature study method. As a result, it shows that SMEs have a promising prospect in facing external and internal challenges and pressures. Thus, this result indicates that SMEs could promote East Java's economy and could be a solution for Indonesia to face the global competition, especially the ASEAN Economic Community (AEC) that will be officially enacted at the end of 2015.
\end{abstract}

Keywords: Processing Industry, Global Competition, ASEAN Economic Community, SMEs

\section{ABSTRAK}

Persaingan global menuntut Indonesia untuk bersaing dengan negara lain di pasar internasional. Jawa Timur merupakan provinsi yang memberikan kontribusi besar terhadap $P D B$ Indonesia. Dari tahun ke tahun, sumber pertumbuhan ekonomi di Jawa Timur masih didominasi oleh industri pengolahan khususnya sektor Usaha Mikro Kecil Menengah (UMKM). Sektor ini mampu memberikan kontribusi lebih dari 50\% terhadap produk domestik bruto (PDB) Jawa Timur. Mengingat, pembangunan sektoral bisa lebih efektif dikerahkan di sektor ini karena merupakan penggerak utama perekonomian Jawa Timur. Selain berkontribusi terhadap PDB, sektor ini juga mampu mengatasi masalah ketenagakerjaan dan pemenuhan permintaan. Untuk mengumpulkan data, penulis menggunakan kuesioner untuk mendapatkan data primer dengan responden pelaku UMKM Jawa Timur. Kemudian data tersebut diolah dengan menggunakan pendekatan Balanced Scorecard untuk mengukur kinerja UMKM. Selain itu, penulis juga menggunakan data sekunder yang diperoleh dengan metode studi kepustakaan. Hal ini menunjukkan bahwa UMKM memiliki prospek yang menjanjikan dalam menghadapi tantangan dan tekanan eksternal dan internal. Dengan demikian, hasil ini menunjukkan bahwa UKM dapat memajukan perekonomian Jawa Timur dan dapat menjadi solusi bagi Indonesia dalam menghadapi persaingan global, khususnya Masyarakat Ekonomi ASEAN (MEA) yang akan resmi diberlakukan pada akhir tahun 2015.

Kata Kunci: Industri Pengolahan, Persaingan Global, Masyarakat Ekonomi ASEAN, UMKM JEL : L6, F6, F1, L3 


\section{PENDAHULUAN}

Saat ini, perlambatan pertumbuhan ekonomi sedang terjadi di Indonesia. Tidak hanya di Indonesia, perlambatan juga terjadi secara global. Di tengah perlambatan yang sedang terjadi, era globalisasi juga terus menuntut persaingan yang ketat antar negara. Bagi Indonesia, persaingan yang semakin nyata akan terjadi pada akhir tahun ini dengan diberlakukannya pasar bebas ASEAN atau biasa disebut dengan Masyarakat Ekonomi ASEAN (MEA). MEA membuka area pasar yang dapat menembus batas suatu negara dimana setiap negara anggota ASEAN dapat dengan bebas menjual barang atau jasanya di wilayah mana pun di Asia Tenggara. Tidak hanya membuka arus barang atau jasa, MEA juga membuka arus tenaga kerja, sehingga tenaga kerja asing akan dapat keluar dan masuk Indonesia dengan mudah. Selain itu, terdapat juga arus modal dan investasi yang berputar di seluruh kawasan Asia Tenggara.

MEA dapat menjadi kesempatan yang baik bagi Indonesia, namun juga dapat menjadi ancaman jika Indonesia tidak siap untuk bersaing dengan negara-negara lain di Asia Tenggara. Di satu sisi, bebasnya arus perdagangan dapat menjadi kesempatan yang baik karena hambatan-hambatan dalam perdagangan akan berkurang sehingga dapat menaikkan komoditas ekspor. Tetapi di sisi lain, barang dari luar negeri dengan kualitas yang lebih baik akan dengan mudah masuk ke pasar Indonesia dalam jumlah yang banyak dan dapat mengancam keberlangsungan industri lokal. Tidak hanya barang, tetapi juga jasa dan sumber daya manusia yang berkualitas dari luar negeri akan dengan mudah masuk ke Indonesia.

Nyatanya, Indonesia saat ini memiliki posisi yang tidak kuat juga tidak lemah di ASEAN. Dari seluruh anggota ASEAN, Indonesia memiliki pertumbuhan ekonomi tertinggi yaitu sebesar 6,4\% (World Bank, 2011) dan meraih posisi ketiga di Asia. Indonesia juga memiliki peta usia penduduk yang cukup muda, sumber daya alam yang melimpah, dan pasar yang besar (Deloitte, 2015). Total PDB Indonesia juga menembus 846 milyar US Dollar di tahun 2011 (Bank Dunia, 2012) yang merupakan yang terbesar di ASEAN dan urutan ke-16 di dunia sehingga membuat Indonesia menjadi satu-satunya anggota ASEAN yang menjadi anggota G20. Sayangnya, tingginya PDB Indonesia tidak sesuai dengan PDB per-kapita yang hanya menempati peringkat ke-5 di ASEAN, di bawah Singapura, Brunei Darussalam, Malaysia, dan Thailand (Bank Dunia, 2012). Selain itu, dari segi daya saing, menurut World Economic Forum (WEF) dalam The Global Competitiveness Report 2013-2014, Indonesia menempati peringkat ke-38 dari 148 negara dan merupakan peringkat ke-5 di ASEAN setelah Singapura (2), Malaysia (24), Brunei Darussalam (26), dan Thailand (37).

Diberlakukannya pasar bebas ASEAN di tengah kondisi perekonomian global yang tidak menentu membuat posisi Indonesia juga terombang-ambing. Hal ini menjadi tekanan eksternal yang harus dihadapi Indonesia. Selain faktor eksternal tersebut, Indonesia juga menghadapi tekanan dari internal negara seperti kualitas infrastruktur dan sumber daya manusia yang kurang, baik dari segi tingkat pendidikan, daya saing, skill, knowledge, dan lain-lain. Selain itu, terjadinya depresiasi rupiah terhadap dollar AS juga mempengaruhi melemahnya kinerja industri di Indonesia yang dipicu oleh tingkat ketergantungan bahan baku impor yang mencapai $40 \%$ sehingga pengusaha akan mengurangi angka produksinya.

Indonesia tidak dapat berdiam diri dengan kondisi yang tidak menentu ini. Banyak kerugian yang akan ditimbulkan jika Indonesia tidak dapat bersaing di pasar bebas ASEAN, salah satunya adalah meningkatnya angka pengangguran karena industri-industri lokal yang tidak dapat bertahan di tengah derasnya arus barang dan jasa dari luar negeri. Indonesia harus mempersiapkan diri dengan meningkatkan kapabilitas dan kualitas, serta memanfaatkan peluang yang ada dalam MEA agar tidak kalah saing di negeri sendiri. Untuk dapat bersaing di 
pasar bebas ASEAN, pemerintah mengambil langkah-langkah untuk menghadapi MEA antara lain penguatan daya saing ekonomi, program Aku Cinta Indonesia $(\mathrm{ACl})$, perbaikan infrastruktur, peningkatan kualitas sumber daya manusia, reformasi kelembagaan dan pemerintah, serta penguatan sektor Usaha Mikro, Kecil, dan Menengah (UMKM).

Usaha Mikro, Kecil, dan Menengah (UMKM) merupakan faktor yang sangat penting dalam perekonomian Indonesia karena merupakan kelompok usaha yang memiliki jumlah paling besar serta memiliki kontribusi yang tinggi terhadap PDB dan penyerapan tenaga kerja. Di Indonesia, pada tahun 2012 , dari total unit usaha sebesar 56,5 juta, sebanyak $99,9 \%$ merupakan UMKM; Usaha Mikro: 98,79\%, Usaha Kecil: 1,11\%, dan Usaha Menengah: 0,09\% (Kementrian Koperasi dan UKM, 2013). Dari total tenaga kerja sebesar 110,8 juta, sebanyak 97,16\% terserap di sektor UMKM; Usaha Mikro: 90,12\%, Usaha Kecil: 4,09\%, Usaha Menengah: 2,94\% (Kementrian Koperasi dan UKM, 2013). Dari total PDB Nasional sebesar Rp8.241,9 triliun, sebanyak 59,08\% berasal dari UMKM; Usaha Mikro: 35,81\%, Usaha Kecil: 9,68\%, Usaha Menengah: 13,59\% (Kementrian Koperasi dan UKM, 2013).

Jawa Timur merupakan provinsi yang banyak memberikan kontribusi pada Negara, terbukti pada tahun 2013, Jawa Timur merupakan provinsi kedua di Pulau Jawa yang memberikan kontribusi PDRB terbesar terhadap PDB nasional yaitu sebesar 15,02\% setelah DKI Jakarta (Sumber: BPS RI). Jika berbicara mengenai UMKM di Indonesia, tentunya juga tidak dapat terlepas dari kontribusi besar UMKM di Jawa Timur. Pada tahun 2012, UMKM di Jawa Timur mampu memberikan kontribusi sebesar 54,48\% terhadap PDRB Jawa Timur (Sumber: BPS Jawa Timur). Jumlah UMKM yang ada juga fantastis yaitu sebesar 6.825.931 unit usaha dan menyerap 11.117.439 tenaga kerja (Sumber: BPS Jawa Timur). Keberadaan UMKM Jawa Timur merupakan salah satu faktor yang dapat memperkuat posisi Indonesia dalam pasar bebas ASEAN.

Secara struktural, perekonomian Jawa Timur dikuasai oleh empat sektor utama yaitu sektor pertanian, sektor industri pengolahan, sektor perdagangan, serta sektor pertambangan dan penggalian. Sektor industri pengolahan merupakan penggerak utama perekonomian Jawa Timur mengingat potensinya yang cukup besar dalam mengatasi masalah ketenagakerjaan, pemenuhan persediaan permintaan domestik, serta keterkaitan yang tinggi dengan sektor lainnya. Pada tahun 2013, industri pengolahan menyumbang $26,60 \%$ dari total PDRB Jawa Timur dan merupakan yang terbesar setelah sektor perdagangan, hotel, dan restoran (BPS Jawa Timur). Kepala Badan Pusat Statistik (BPS) Jawa Timur, Sairi Hasbullah, mengatakan bahwa sumber pertumbuhan Jawa Timur secara year-on-year masih didominasi oleh industri pengolahan yang mencapai 1,58\%, meskipun turun dari kuartal pertama tahun 2014 yang mencapai $2,57 \%$. Penurunan angka pertumbuhan ini disebabkan oleh menurunnya geliat perekonomian Jawa Timur akibat melemahnya tren ekonomi nasional.

Sektor industri pengolahan dan Usaha Mikro, Kecil, dan Menengah (UMKM) merupakan hal yang tidak dapat dipisahkan karena keduanya merupakan pemegang peranan terpenting dalam perekonomian Jawa Timur, sesuai dengan bidangnya masing-masing. Pada tahun 2011, dari 783.758 unit usaha industri pengolahan di Jawa Timur, sebanyak 97,8\% merupakan industri kecil dan 2,07\% merupakan industri menengah (BPS Jawa Timur). Industri kecil mampu menyerap 1.756.587 tenaga kerja dan industri menengah mampu menyerap 917.062 tenaga kerja (BPS Jawa Timur). Nilai produksi industri kecil mencapai 68 milyar rupiah atau naik 4,76\% dari tahun 2010 dan industri menengah mencapai 52,1 milyar rupiah atau naik 3,74\% dari tahun 2010 (BPS Jawa Timur). Usaha Mikro, Kecil, dan Menengah (UMKM) yang bergerak di sektor industri pengolahan tentunya memiliki peranan penting dalam perekonomian Jawa 
Timur. Dalam penelitian ini, peneliti ingin melihat kinerja dan potensi yang dimiliki oleh Usaha Mikro, Kecil, dan Menengah (UMKM) pada sektor industri pengolahan Jawa Timur dalam menghadapi tantangan persaingan global.

Berdasarkan latar belakang tersebut, peneliti akan melakukan analisis mengenai kinerja UMKM sektor industri pengolahan Jawa Timur. Analisis juga mencoba menjawab potensi yang dimiliki oleh UMKM sektor industri pengolahan Jawa Timur untuk dapat bersaing dalam persaingan global, serta prospek UMKM sektor industri pengolahan Jawa Timur dalam menghadapi tekanan dari internal maupun eksternal. Hasil penelitian tersebut diharapkan dapat memberikan jawaban tentang tingkat resiliensi perekonomian Jawa Timur di tengah perlambatan global dan domestik, potensi Jawa Timur dalam menghadapi persaingan global dengan mengandalkan keberadaan UMKM sektor industri pengolahan, prospek UMKM sektor industri pengolahan Jawa Timur di tengah tekanan internal dan eksternal serta memberikan rekomendasi dalam perumusan strategi guna mendorong pertumbuhan ekonomi Jawa Timur yang inklusif dan berkesinambungan.

Beberapa hal yang dapat menjadi keterbatasan penelitian yaitu penelitian ini dilaksanakan pada bulan Oktober-November 2015 dimana pengambilan data primer hanya dilakukan pada pelaku UMKM di Jawa Timur dan tidak melibatkan pelanggan dalam pengambilan data. Perspektif pelanggan yang digunakan dalam pengolahan data didapatkan dari kondisi aktual yang ditanyakan kepada pelaku UMKM. Kondisi tersebut dianggap mampu menggambarkan sudut pandang pelanggan. Sampel yang digunakan dalam penelitian berjumlah 30 orang pelaku UMKM yang berbeda. Selain itu, data primer yang didapatkan tidak mencakup semua bidang usaha yang termasuk ke dalam sektor industri pengolahan. Data primer yang dianalisis dilihat dari kecenderungan selama 6 bulan terakhir (Maret-Oktober 2015) dan data sekunder yang dianalisis dilihat dari kenaikan PDRB dari tahun 2009-2012.

\section{TINJAUAN PUSTAKA}

\section{Studi Terdahulu}

Dalam penelitian ini, penulis menggunakan referensi dari dua penelitian terdahulu yang relevan dengan permasalahan yang akan diteliti, yaitu:

Tabel 1: Penelitian Terdahulu

\begin{tabular}{|c|c|c|c|c|}
\hline Penulis & Judul & Metode & Hasil & Perbedaan \\
\hline $\begin{array}{l}\text { Dian Ramadhani } \\
\text { (30402288) } \\
\text { Jurusan Teknik } \\
\text { Industri Univer- } \\
\text { sitas Gunadarma }\end{array}$ & $\begin{array}{l}\text { Analisis Kinerja } \\
\text { UKM Pengolahan } \\
\text { Keripik Pisang di } \\
\text { Bandar Lampung } \\
\text { dengan Menggu- } \\
\text { nakan Metode } \\
\text { Quality Function } \\
\text { Deployment }\end{array}$ & $\begin{array}{l}\text { Wawancara, } \\
\text { penyebaran } \\
\text { kuesioner, } \\
\text { studi literatur, } \\
\text { benchmarking }\end{array}$ & $\begin{array}{l}\text { Strategi perbaikan } \\
\text { dengan QFD dan } \\
\text { prioritas perbaikan } \\
\text { strategi tolok } \\
\text { ukur kinerja UK } \\
\text { pengolahan keripik } \\
\text { pisang }\end{array}$ & $\begin{array}{l}\text { Penelitian pada paper } \\
\text { bertujuan untuk mengeta- } \\
\text { hui kinerja dan potensi dari } \\
\text { UMKM Industri Pengolahan } \\
\text { di Jawa Timur }\end{array}$ \\
\hline $\begin{array}{l}\text { Boy Isma Putra, } \\
\text { ST, MM. (Dosen } \\
\text { Teknik Industri } \\
\text { Unmuh Sidoarjo) }\end{array}$ & $\begin{array}{l}\text { Analisis Pen- } \\
\text { gukuran Kinerja } \\
\text { dengan Metode } \\
\text { Balance Score } \\
\text { Card (BSC) Di CV } \\
\text { MCH Sidoarjo }\end{array}$ & $\begin{array}{l}\text { Penyebaran } \\
\text { kuesioner dan } \\
\text { studi literatur }\end{array}$ & $\begin{array}{l}\text { Pengukuran kiner- } \\
\text { ja } \mathrm{CV} \mathrm{MCH}\end{array}$ & $\begin{array}{l}\text { Penelitian pada paper meng- } \\
\text { gunakan metode AHP dan } \\
\text { BSC pada sample UMKM } \\
\text { yang ada untuk kemudian } \\
\text { digeneralisasi sebagai kiner- } \\
\text { ja UMKM industri pengolah- } \\
\text { an Jawa Timur }\end{array}$ \\
\hline
\end{tabular}




\section{Telaah Literatur}

\section{Masyarakat Ekonomi ASEAN (MEA) 2015}

ASEAN merupakan suatu komunitas yang terdiri dari negara-negara di kawasan Asia Tenggara yang terdiri atas 10 negara yaitu Indonesia, Malaysia, Filipina, Singapura, Thailand, Brunei Darussalam, Vietnam, Laos, Myanmar, dan Kamboja. Pada akhir tahun 2015, negara-negara ini membentuk sebuah kawasan yang terintegrasi yang dinamakan ASEAN Economic Comunity (AEC) atau Masyarakat Ekonomi ASEAN (MEA).

MEA merupakan sebuah kawasan ekonomi ASEAN yang terintegrasi dimana akan dibuka pasar bebas antar negara-negara ASEAN. Tujuan dibentuknya MEA adalah untuk meningkatkan stabilitas perekonomian di wilayah ASEAN, juga untuk mengatasi masalah-masalah yang terjadi di bidang ekonomi antar negara ASEAN. Dengan diberlakukannya MEA, akan terdapat arus bebas barang, jasa, investasi, tenaga kerja, dan modal serta investasi. Dalam menghadapi persaingan yang ketat se-ASEAN, negara-negara ASEAN haruslah mempersiapkan sumber daya manusia (SDM) yang berkualitas dan dapat bersaing.

Terdapat empat hal yang menjadi fokus MEA pada tahun 2015. Pertama, negara-negara di kawasan Asia Tenggara akan dijadikan sebuah wilayah kesatuan pasar dan basis produksi. Kedua, MEA akan dibentuk sebagai kawasan ekonomi dengan tingkat kompetisi yang tinggi, yang memerlukan suatu kebijakan yang meliputi competition policy, consumer protection, Intellectual Property Rights (IPR), taxation, dan E-Commerce. Ketiga, MEA akan dijadikan sebagai kawasan yang memiliki perkembangan ekonomi yang merata dengan memperhatikan Usaha Kecil Menengah (UKM). Keempat, MEA akan diintegrasikan secara penuh terhadap perekonomian global dengan membangun sebuah sistem untuk meningkatkan koordinasi antar negara-negara ASEAN.

\section{Industri Pengolahan}

Industri pengolahan merupakan suatu kegiatan ekonomi yang mengubah bahan baku menjadi barang jadi/setengah jadi secara mekanis, kimia, atau dengan tangan. Atau dapat didefinisikan sebagai penambahan nilai terhadap suatu barang yang lebih rendah nilainya menjadi barang yang lebih tinggi nilainya. Industri pengolahan sifatnya lebih dekat kepada pemakai akhir dan biasa disebut sebagai industri sekunder dimana bahan mentah diolah menjadi barang-barang untuk dikonsumsi atau diolah kembali.

Survei industri pengolahan menggunakan klasifikasi yang berdasarkan pada International Standard Industrial Classification of all Economic Activities (ISIC) revisi keempat, yang telah disesuaikan dengan kondisi di Indonesia dan dinamai Klasifikasi Baku Lapangan Usaha Indonesia (KBLI) tahun 2009. Kode baku lapangan usaha suatu perusahaan industri ditentukan berdasarkan produksi utamanya atau komoditas yang dihasilkan dengan nilai paling besar.

\section{Usaha Mikro, Kecil, dan Menengah (UMKM)}

Klasifikasi usaha berdasarkan jumlah tenaga kerja yang merupakan suatu tolak ukur yang digunakan oleh Badan Pusat Statistik (BPS) untuk menilai usaha kecil atau besar yaitu: usaha mikro (1-4 orang), usaha kecil (5-19 orang), usaha menengah (20-99 orang) dan usaha besar (>100 orang). Sementara karakteristik masing-masing tergambar dalam tabel 2. 
Tabel 2: Klasifikasi Usaha Berdasarkan Jumlah Tenaga Kerja

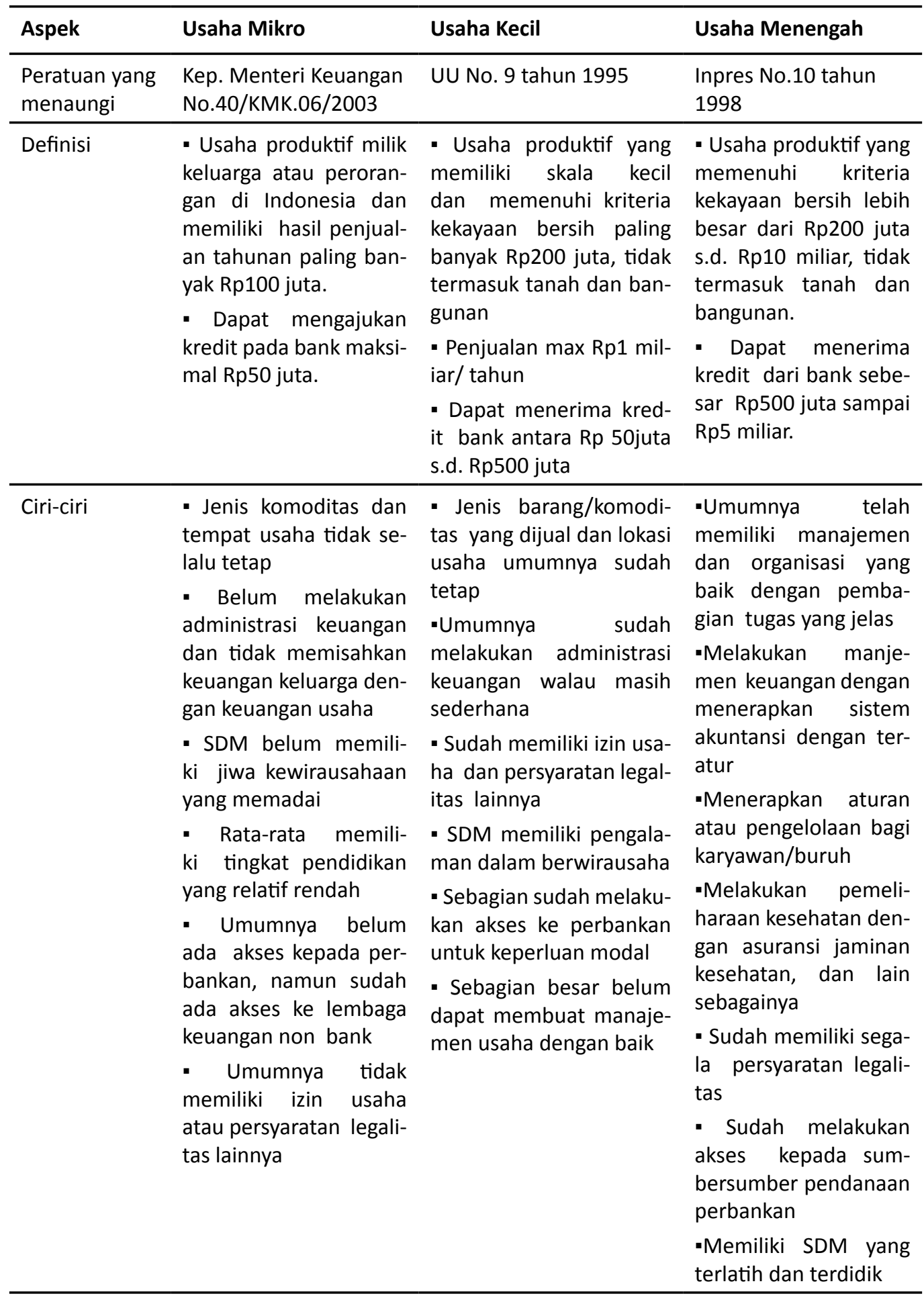

\section{Balanced Scorecard}

Balanced scorecard (kartu skor) adalah kartu yang digunakan untuk mencatat hasil kinerja seseorang. Kartu skor juga dapat digunakan untuk merencanakan skor yang hendak dicapai di masa yang akan datang. Melalui kartu skor, skor yang hendak dicapai di masa yang akan datang dibandingkan dengan hasil kinerja yang sesungguhnya. Hasil perbandingan ini digunakan untuk melakukan evaluasi atas kinerja seseorang atau sebuah perusahaan. Kinerja yang diukur haruslah berimbang antara aspek keuangan dan non keuangan, aspek jangka 
pendek dan jangka panjang, serta aspek internal dan eksternal. Keunggulan metode balanced scorecard dalam sistem perencanaan strategis adalah metode ini mampu menghasilkan rencana strategi yang komprehensif, koheren, seimbang, dan terukur.

Metode balanced scorecard memberikan kerangka untuk menjabarkan visi ke dalam sasaran-sasaran strategi yang komprehensif dengan menggunakan empat perspektif yaitu keuangan/finansial, pelanggan, proses bisnis internal, serta pembelajaran dan pertumbuhan (Kaplan dan Norton, 1992).

1. Perspektif keuangan/finansial memberikan sasaran keuangan yang perlu dicapai oleh organisasi dalam mewujudkan visinya. Ukuran keuangan merupakan suatu gambaran mengenai pencapaian secara ekonomi yang terjadi di perusahaan. Pengukuran kinerja keuangan menunjukkan apakah perencanaan dan pelaksanaan serta strategi keuangan memberikan perbaikan.

2. Perspektif pelanggan memberikan gambaran mengenai segmen pasar yang dituju dan kepuasan pelanggan terhadap kinerja organisasi.

3. Perspektif bisnis internal memberikan gambaran proses yang harus dibangun untuk memenuhi kebutuhan pelanggan. Menurut Kaplan dan Norton (1996), proses bisnis internal terdiri dari tiga tahapan yaitu inovasi, operasi, dan layanan purna jual.

4. Perspektif pembelajaran dan pertumbuhan (learning and growth) merupakan pemacu untuk membangun kompetensi dari karyawan dan suasana lingkungan kerja yang diperlukan untuk mencapai sasaran organisasi.

Tabel 3: Tolok Ukur Kinerja Perspektif Balance Scorecard

\begin{tabular}{ll}
\hline Perspektif & Tolok Ukur Kinerja \\
\hline Keuangan/finansial & - Return on equity (ROE) = Net Income / Net Worth \\
- Economic Value Added (EVA) $=\left(r-c^{*}\right)$. Capital \\
Dimana : $r=$ corporate economic return; c* = opportunity \\
cost of debitur and quity \\
- Break Event Point (BEP) = Fixed Cost / (Price - Variable Cost) \\
- Net Profit Margin (NPM) = Net Income / Sales \\
- Sales Growth, Return on Investment (ROI), Return on Asset \\
(ROA), dan lain sebagainya. \\
\hline Pelanggan & $\begin{array}{l}\text { Pangsa pasar, tingkat perolehan pelanggan baru, kemampuan } \\
\text { perusahaan mempertahankan para pelanggan lama, tingkat } \\
\text { kepuasan pelanggan, tingkat profitabilitas pelanggan, atribut } \\
\text { atribut produk (harga, kualitas, fungsi), hubungan dengan pe- } \\
\text { langgan, reputasi perusahaan, on time delivery, number of } \\
\text { complaints, sales return, dan lain sebagainya. }\end{array}$ \\
\hline Bisnis Internal & $\begin{array}{l}\text { Supplier lead time, jumlah produk rusak/cacat, jumlah ke- } \\
\text { celakaan kerja, jumlah kerusakan peralatan, banyak kerjasama } \\
\text { dengan pihak lain, dan lain sebagainya }\end{array}$ \\
\hline $\begin{array}{l}\text { Pembelajaran dan } \\
\text { and growth) }\end{array}$ & $\begin{array}{l}\text { Employe productivity, employee turn over, tingkat absensi, } \\
\text { banyak pelatihan yang diikuti dan lain sebagainya. }\end{array}$ \\
\hline
\end{tabular}




\section{Analytical Hierarchy Process (AHP)}

Proses pengambilan keputusan pada dasarnya adalah memilih suatu alternatif. AHP merupakan suatu metode pengambilan keputusan dengan input utamanya adalah persepsi manusia. Masalah-masalah yang kompleks dan tidak terstruktur dipecahkan ke dalam kelompok-kelompoknya, kemudian kelompok kelompok tersebut diatur menjadi suatu hierarki. Sebelum menetapkan suatu tujuan, dilakukan tes kepentingan mengenai apakah suatu tindakan/hasil yang terbaik akan diperoleh bila tujuan tersebut tidak dijabarkan dalam proses evaluasi. Metode AHP memiliki kelebihan-kelebihan, antara lain memiliki struktur yang berhierarki mempermudah pengelompokkan dan metode ini memperhatikan validitas dari berbagai kriteria dan alternatif yang dipilih oleh para pengambil keputusan dan memperhitungkan daya tahannya.

Prosedur AHP dikelompokkan dalam lima langkah, yaitu: (i) Pembangunan model AHP, (ii) Pairwise comparison yaitu membandingkan alternatif-alternatif yang ada berdasarkan tingkat kepentingan dengan skala 1-9 dari yang memiliki tingkat kepentingan sama (1) sampai tingat kepentingan mutlak dimiliki oleh salah satu alternatif saja (9), (iii) Cek konsistensi, (iv) Evaluasi keseluruhan bobot, (v) Kebijakan grup pengambil keputusan.

Saat ini banyak terdapat perangkat lunak untuk melakukan pengambilan keputusan seperti Expert Choice, Super Decision, dan lain sebagainya. Dalam penelitian ini, penulis menggunakan perangkat lunak Expert Choice untuk menentukan bobot dari masing-masing alternatif.

\section{METODE PENELITIAN}

Penelitian ini adalah penelitian eksploratif dan langkah-langkah yang digunakan dalam penelitian ini adalah persiapan dan pendahuluan, pelaksanaan (melalui studi literatur, penyusunan instrumen penelitian yaitu kuesioner, dan pengumpulan data) dan analisis data.

Pengumpulan data dilakukan dengan metode kuesioner dan wawancara sesuai dengan target responden yaitu dengan menyebar kuesioner mengenai kinerja UMKM industri pengolahan di Jawa Timur ke 30 orang pelaku UMKM sebagai data primer.

Setelah data didapat, data diolah dengan menggunakan metode Analytical Hierarchy Process (AHP) guna menentukan bobot pada masing-masing alternatif untuk nantinya digunakan pada Balanced Scorecard. Terdapat 4 kelompok yang dianalisa dalam Balanced Scorecard, yaitu perspektif finansial, pelanggan, bisnis internal, serta pembelajaran dan pertumbuhan. Terdapat juga 1 kelompok besar yaitu kinerja secara keseluruhan. Pembuatan AHP dibagi berdasarkan 4 kelompok tersebut dengan kriterianya adalah masing-masing UMKM (terdapat 30 UMKM yang dijadikan sample) dan alternatifnya adalah tolak ukur yang digunakan pada masing masing kelompok. Sehingga terdapat 150 matriks, termasuk matriks untuk kinerja keseluruhan.

Setelah itu, dilakukan perhitungan nilai dengan metode Balanced Scorecard dengan mengalikan bobot dengan skor sehingga didapatkan nilai yang menggambarkan baik atau tidaknya pencapaian perusahaan (nilai 1 tidak baik, 2 cukup baik, 3 baik). Setelah didapatkan hasil, penulis dapat menarik kesimpulan dan memberikan saran/rekomendasi.

Selain menggunakan hasil dari pengolahan data primer, untuk menentukan apakah UMKM industri pengolahan Jawa Timur memiliki potensi dan prospek yang baik dalam menghadapi MEA, penulis juga melakukan analisis terhadap data yang berkaitan dengan pertumbuhan ekonomi Jawa Timur dari tahun ke tahun, juga kontribusi UMKM industri pengolahan terhadap pertumbuhan tersebut. 
\begin{tabular}{l|l} 
Ibrahim, A.R & Potential of Micro, Small And Medium Business (MSME) Processing Industry
\end{tabular} Sector East Java in Responding to The Challenges of Globalization

\section{HASIL DAN PEMBAHASAN}

Untuk mengumpulkan data, penulis menyebar 30 buah kuesioner kepada pelaku UMKM di Jawa Timur. Berikut adalah rincian responden yang mengisi kuesioner:

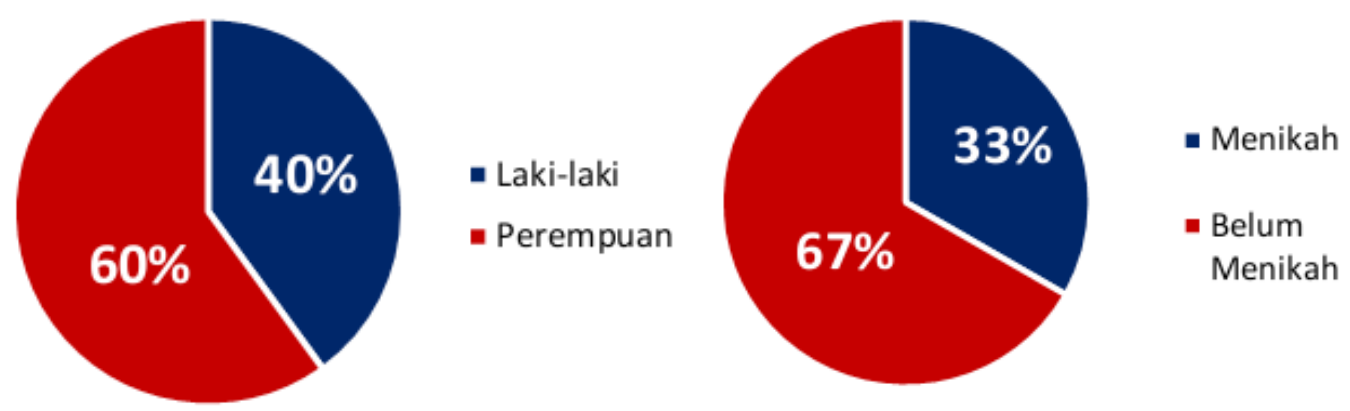

Grafik 1: Jenis Kelamin Responden

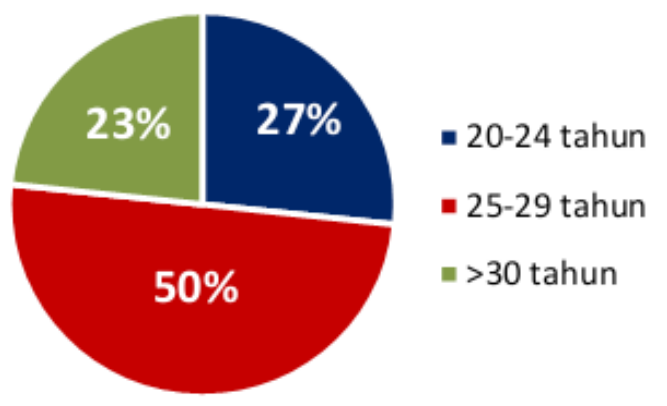

Grafik 3:Usia Responden

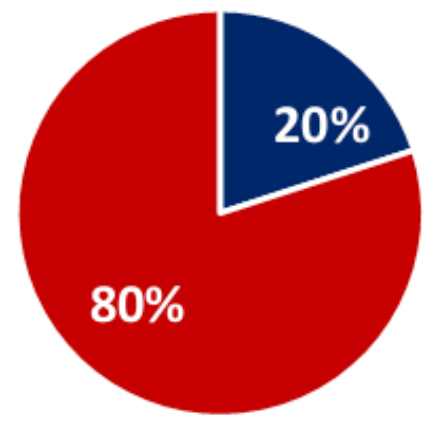

- 2005-2009 - 2010-2015

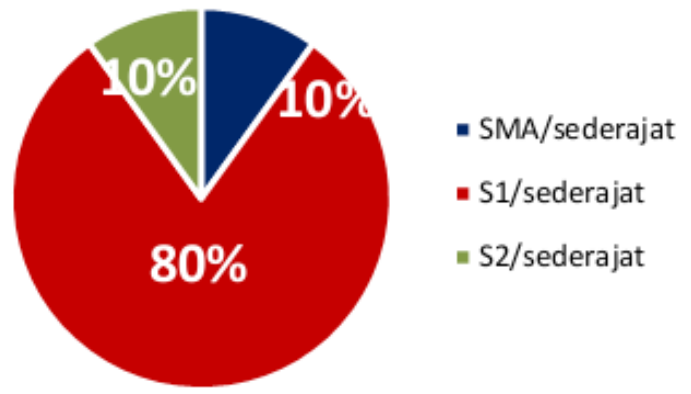

Grafik 4: Tingkat Pendidikan Responden

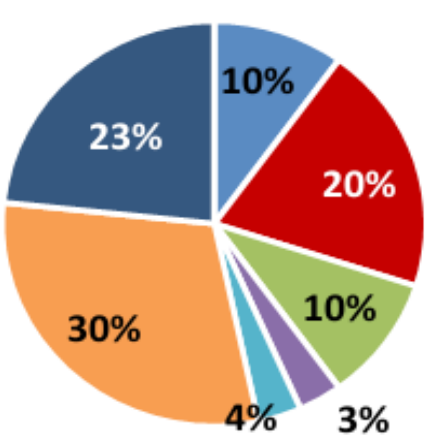

= Barang dari karet dan plastik

- Barang dari kayu, bambu, gabus, rotan, dsb

- Barang dari kulit dan alas

kaki

- Barang da ri logam

- Barang dari ketas

- Makanan dan Minuman

- Pakaian

\section{Grafik 5: Tahun Berdirinya Usaha}

Grafik 6: Bidang Usaha

Data yang sudah didapat kemudian diolah dengan menggunakan metode AHP dan Balanced Scorecard. Tolak ukur atau parameter yang digunakan dalam Balanced Scorecard dibuat berdasarkan 4 kelompok perspektif yang mewakili kinerja perusahaan, baik dari segi internal maupun eksternal. Rincian parameter yang digunakan oleh penulis dibuat dengan mempertimbangkan objek penelitian, cara pengambilan data, elemen-elemen yang ada dalam kuesioner, durasi penelitian, dan beberapa hal lainnya sehingga didapatkan parameter yang memungkinkan untuk digunakan dalam penelitian, yaitu: 
Tabel 4: Parameter Balance Scorecard dalam Penelitian

\begin{tabular}{cc}
\hline Perspektif Finansial & Perspektif Pelanggan \\
\hline - Break Even Point (BEP) & - Banyak variasi produk \\
- Return on Equity (ROE) & - Jumlah pelanggan yang membeli produk \\
- Net Profit Margin & - Jumlah pelanggan setia (membeli produk \\
& lebih dari sekali) \\
& - Jumlah komplain \\
Perspektif Bisnis Internal & - Banyak jenis promosi \\
- Jumlah inspeksi dalam pembuatan 1 pro- & - Tingkat keluar masuk pekerja (turnover) \\
- Banyaknya kerjasama dengan pihak lain & - Employee productivity \\
- Jumlah produk yang rusak atau cacat & - Tingkat absensi \\
- Berapa lama karyawan bekerja (untuk me- \\
lihat pengalaman dan kemampuan kerja) \\
- Jumlah kecelakaan
\end{tabular}

Dari masing-masing parameter tersebut, data yang didapat dari 30 UMKM dirata ratakan untuk menentukan skor masing-masing parameter.

Sebelum menggunakan Balanced Scorecard, bobot dihitung dengan menggunakan metode AHP. Kemudian perhitungan skor dilakukan dengan menggunakan Balanced Scorecard. Bobot dan skor yang sudah didapat dikalikan sehingga didapatkan nilai:

Tabel 5: Pengukuran Kinerja Masing-masing Perspektif

\begin{tabular}{|c|c|c|c|c|}
\hline Indikator & Bobot & Skor & Nilai & Jumlah \\
\hline \multicolumn{5}{|l|}{ PERSPEKTIF FINANSIAL } \\
\hline BEP & 0,488 & 3 & 1,464 & \multirow{4}{*}{$\begin{array}{l}2,643 \\
\text { (Baik) }\end{array}$} \\
\hline ROE & 0,251 & 2 & 0,502 & \\
\hline EVA & 0,157 & 3 & 0,471 & \\
\hline Net Profit Margin & 0,103 & 2 & 0,206 & \\
\hline \multicolumn{5}{|l|}{ PERSPEKTIF PELANGGAN } \\
\hline Banyak Variasi Produk & 0,302 & 2 & 0,604 & \multirow{6}{*}{$\begin{array}{c}2,342 \\
\text { (Cukup } \\
\text { Baik) }\end{array}$} \\
\hline Jumlah Pelanggan & 0,222 & 3 & 0,666 & \\
\hline Jumlah Pelanggan Setia & 0,142 & 2 & 0,284 & \\
\hline Jumlah Komplain & 0,131 & 2 & 0,262 & \\
\hline Banyak Jenis Promosi & 0,086 & 2 & 0,172 & \\
\hline $\begin{array}{l}\text { Jumlah Keterlambatan Pengiriman } \\
\text { Produk }\end{array}$ & 0,118 & 3 & 0,354 & \\
\hline \multicolumn{5}{|l|}{ LEARNING AND GROWTH } \\
\hline Employee Turnover & 0,454 & 3 & 1,362 & \multirow{4}{*}{$\begin{array}{l}2,614 \\
\text { (Baik) }\end{array}$} \\
\hline Employee Productivity & 0,286 & 2 & 0,572 & \\
\hline Tingkat Absensi & 0,160 & 3 & 0,48 & \\
\hline Banyak Pelatihan yang Diikuti & 0,100 & 2 & 0,2 & \\
\hline
\end{tabular}




\begin{tabular}{lllll}
\hline \multicolumn{1}{c}{ Indikator } & Bobot & Skor & Nilai & Jumlah \\
\hline \multicolumn{1}{c}{ BISNIS INTERNAL } & & & & \\
\hline Jumlah Inspeksi & 0,298 & 2 & 0,596 & 2,215 \\
\cline { 1 - 4 } Banyak Kerjasama & 0,254 & 2 & 0,508 & (Cukup \\
\cline { 1 - 4 } Jumlah Produk Rusak/Cacat & 0,146 & 3 & 0,438 & Baik) \\
\cline { 1 - 4 } Pengalaman Karyawan & 0,119 & 2 & 0,238 & \\
\hline Jumlah Kecelakaan & 0,114 & 2 & 0,228 & \\
\hline Jumlah Kerusakan Mesin/Alat & 0,069 & 3 & 0,207 & \\
\hline
\end{tabular}

Tabel 6: Pengukuran Kinerja Keseluruhan

\begin{tabular}{|c|c|c|c|c|}
\hline \multicolumn{5}{|l|}{ KINERJA KESELURUHAN } \\
\hline Kategori & Bobot & $\begin{array}{l}\text { Nilai/ } \\
\text { Skor }\end{array}$ & Jumlah & Total \\
\hline Finansial & 0,454 & 2,643 & 1,200 & \multirow{4}{*}{$\begin{array}{l}2,486 \\
\text { (Cukup } \\
\text { Baik) }\end{array}$} \\
\hline Pelanggan & 0,286 & 2,342 & 0,670 & \\
\hline Bisnis Internal & 0,160 & 2,215 & 0,355 & \\
\hline Learning and Growth & 0,1 & 2,614 & 0,261 & \\
\hline
\end{tabular}

Dari pengukuran kinerja masing-masing kategori dapat dilakukan perhitungan terhadap kinerja UMKM secara keseluruhan dan didapatkan nilai 2,486 yang mengindikasikan bahwa kinerja UMKM di Jawa Timur sudah cukup baik, bahkan mendekati baik. Potensi terbesar UMKM Jawa Timur dapat dilihat pada skor terbesar yaitu pada perspektif finansial, diikuti dengan learning and growth, perspektif pelanggan, dan bisnis internal.

Pencapaian dari UMKM di Jawa Timur belum sepenuhnya baik dan masih banyak kekurangan dalam beberapa hal, namun potensi-potensi yang dimiliki dapat terus digali dan kekurangan-kekurangan dapat terus diperbaiki. Potensi ini dapat terus dikembangkan apabila ada peran dari semua pihak di dalamnya, terutama

kebijakan pemerintah. Dalam RPJMD Jawa Timur 2014-2019, pemerintah Jawa Timur mencanangkan beberapa program unggulan yang berfokus pada UMKM, yaitu:

1. Program Pengembangan Industri Kecil dan Menengah Indikator yang akan dicapai melalui program ini adalah jumlah IKM yang mendapatkan pembinaan, jumlah industri besar yang difasilitasi.

2. Program Peningkatan Kapasitas Teknologi Industri Indikator yang akan dicapai melalui program ini adalah jumlah IKM yang mendapatkan pelayanan teknis, frekuensi pelayanan yang diberikan.

3. Program Peningkatan Kualitas Sumber Daya Manusia Indikator yang akan dicapai melalui program ini adalah jumlah IKM yang mendapatkan pelatihan, pembinaan dan pendampingan.

4. Program Peningkatan Standardisasi Industri

Indikator yang akan dicapai melalui program ini adalah jumlah IKM yang difasilitasi, jumlah industri yang dibina.

Dengan peran dari semua pihak, keberadaan UMKM Jawa Timur dapat menjadi angin segar dan menjadi solusi bagi Jawa Timur dalam bertahan di tengah arus persaingan global, khususnya MEA 2015. Kontribusi UMKM terhadap PDRB juga terus meningkat dari tahun ke tahun. Di tahun 2009 sebesar 53,49\%, 2011 sebesar 53,82\%, 2012 sebesar 54,34\%, dan 2012 
sebesar 54,48\%. Melihat tren kenaikan ini, di tahun-tahun mendatang UMKM juga diprediksi dapat terus meningkatkan kontribusinya tidak hanya terhadap PDRB tetapi juga PDB Nasional.

\section{KESIMPULAN DAN SARAN \\ Kesimpulan}

Berdasarkan latar belakang, rumusan masalah dan pembahasan, maka kesimpulan dalam studi ini adalah:

1. Dari perspektif keuangan, nilai dari UMKM di Jawa Timur adalah baik.

2. Dari perspektif pelanggan, nilai dari UMKM di Jawa Timur cukup baik.

3. Dari bisnis internal, nilai dari UMKM di Jawa Timur adalah cukup baik.

4. Dari perspektif pembelajaran dan pengembangan, nilai dari UMKM di Jawa Timur adalah baik.

5. Kinerja keseluruhan UMKM di Jawa Timur adalah cukup baik dan dapat mencapai kriteria baik jika terus dikembangkan.

6. Kebijakan dan program pemerintah yang dirancang banyak berfokus pada UMKM yang dapat menjadi angin segar bagi perekonomian Jawa Timur.

7. Kondisi perekonomian Jawa Timur cenderung selalu mengalami peningkatan dalam pertumbuhan ekonomi dan PDRB. Kontribusi UMKM Jawa Timur terhadap PDRB selalu meningkat dari tahun ke tahun.

8. UMKM Jawa Timur memiliki potensi untuk menjadi lebih besar dan menjadi pesaing yang disegani dalam pasar bebas ASEAN jika terus dibina dan dikembangkan, juga membutuhkan keterlibatan semua pihak.

Saran

1. Semua pihak harus terlibat dalam pengembangan UMKM, mulai dari pelaku UMKM itu sendiri sampai pemerintah.

2. Peningkatan kualitas sumber daya manusia menjadi kunci utama dalam menghadapi MEA, sehingga pelaku UMKM dan karyawannya harus dibekali dengan pengetahuan dan skill yang kompetitif.

3. Peningkatan pada infrastruktur juga perlu diperhatikan karena berpengaruh banyak terhadap kinerja UMKM.

\section{DAFTAR PUSTAKA}

Andry, Gusti dan Amrin, Ismadi. "Daya Saing SDM dan UMKM Faktor Penting Hadapi MEA 2015" http://infopublik.id/read/96616/daya-saing-sdm-dan-umkm faktor-penting-hadapi-mea-2015.html/, 2014.

Association of Southeast Asian Nations, (2008), ASEAN Economic Community Blueprint, Asean Secretariat, Jakarta.

Bangun. "Analisis Kinerja UKM Pengolahan Keripik Pisang Di Bandar Lampung Menggunakan Metode SWOT dan Balanced Scorecard”, Mimeo, Universitas Gunadarma, 2007.

Badan Perencanaan Pembangunan Daerah Jawa Timur. "Koperasi dan UMKM Jadi Modal Dahsyat" http://bappeda.jatimprov.go.id/2013/07/23/koperasi-dan umkm-jadi-modal-dahsyat/, 2013.

Dharma, S., dan Sunatrio, Y. "Human Resources Scorecard: Suatu Model Pengukuran Kinerja SDM", Majalah Usahawan No 11 TH XXX, 2001. 
Ibrahim, A.R $\quad$ Potential of Micro, Small And Medium Business (MSME) Processing Industry Sector East Java in Responding to The Challenges of Globalization

Fakultas Peternakan Universitas Gadjah Mada. http://fapet.ugm.ac.id/home/berita 242-fokus-dan-pentingnya-masyarakat-ekonomi-asean-2015.html/ , 2015.

Fernandez, R. A. (2014), YEARENDER: Asean Economic Community to Play Major Role in SEA Food Security.

Mandiri, Ardi. "Kemenkeu Tegaskan Perlambatan Ekonomi Tak Cuma di Indonesia" http://www.suara.com/bisnis/2015/10/21/231200/kemenkeu-tegaskan perlambatan-ekonomi-tak-cuma-di-indonesia/, 2015.

“Pahami Masyarakat Ekonomi ASEAN (MEA) 2015” http://nationalgeographic.co.id/berita/2014/12/pahami-masyarakat-ekonomi asean-mea-2015/, 2015.

Pemerintah Provinsi Jawa Timur, (2009), RPJMD Jawa Timur 2009-2014, Pemerintah Provinsi Jawa Timur, Jawa Timur.

Pemerintah Provinsi Jawa Timur, (2014), RPJMD Jawa Timur 2014-2019, Pemerintah Provinsi Jawa Timur, Jawa Timur.

Plummer, M, G., dan Yue, C. S. (2009), Realizing the ASEAN Economic Community: A Comprehensive Assessment. Singapore: Institute of Southeast Asian Studies.

Ramadhani, Dian. "Analisis Kinerja UKM Pengolahan Keripik Pisang Di Bandar Lampung Dengan Menggunakan Metode Quality Function Deployment", Mimeo, Universitas Gunadarma, 2014.

Santoso, W. (2008). Outlook Ekonomi Indonesia 2008-2012: Integrasi ekonomi ASEAN dan prospek perekonomian nasional. Jakarta: Biro Riset Ekonomi Direktorat Riset Ekonomi dan Kebijakan Moneter.

Teresia, Ananda W. "Industri Kecil di Jawa Timur Tumbuh Pesat” https://bisnis.tempo.co/read/ news/2012/11/20/090442924/industri-kecil-di jawa-timur-tumbuh-pesat/, 2012

Tunggal, A.W. (2002), Memahami Konsep Balanced Scorecard, Harvarindo, Jakarta.

Utama, I Gusti Bagus Rai. “Analisis Kerja Menggunakan Balance Scorecard” http://www.researchgate.net/publication/280233016_ANALISIS_KINERJA_ME NGGUNAKAN_BALANCED_SCORECARD_\%28BSC\%29/, 2009. 